\title{
ПСИХОЛОГИЈАТА НА СЕБСТВОТО ВО ДЕНЕШНО ВРЕМЕ *
}

\author{
Благоја Јанаков ${ }^{1}$

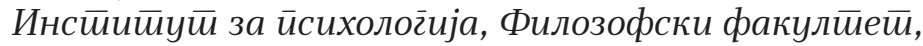

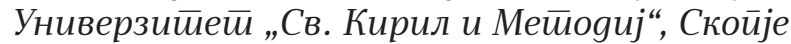 \\ (во иеензија)
}

\section{Кратка содржина}

Психологијата на себството е област во која последните децении многу се работи. Себството е една од неколкүте најмногу изучувани појави во современата психологија. Според многу психолози, особено од С Америка, себството е најважен или главен дел/ потсистем на личноста. Факт е дека научната слика за себството последните десетлетија значително се усложни. Особено се усложни сликата за процесуалните појави, за функционирањето на себството. Значително се обогатени сознанијата за поврзаноста на себството (кое некои научници го нарекоа највнатрешната, најпсихолошката психичка појава) со светот, особено со социјалниот контекст. Дел од текстот е за клучната компонента на себството - себеоценката/себепочитувањето. Создадени се бројни сфаќања за разни делови, аспекти, механизми и др. Поставени се бројни нови прашања. Меѓутоа, клучните прашања за себството сѐ уште не се убедливо и аргументирано одговорени.

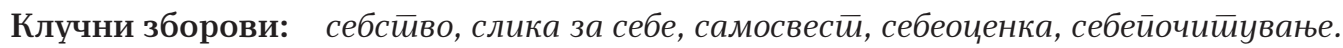

\footnotetext{
${ }^{1}$ blagoja@fzf.ukim.edu.mk

*Найомена. Статијата претставува изменет текст на пленарно предавање „Психологијата на себството во претходните триесетина години“, одржано на Меѓународната конференција по психологија „Психологија за сите“ од 26 до 28 септември 2019 г. во Охрид, Република Македонија. Повод за предавањето беше триесетгодишнината од печатењето на книгата „Психологија на самосвеста“" (Janakov, 1988).
} 


\section{Вовед}

Воопштено кажано, себството било малку изучувано и не било сметано за главен или за мошне важен дел на личноста или менталноста до 70-тите г. на минатиот век. Почетоците на научното изучување се во втората половина на 19 век (Сеченов, 1947; James, 1950) и првите десетлетија на 20 век (Ч. Кули, Џ. Мид и др.). Во средината на 20 век го изучуваа мал број психолози: Ананјев (Ананьев, 1980), Валон (Валон, Зазо, 1988, Valon, 1985), Ериксон (Erikson, 1963), Олпорт (Olport, 1969), Роџерс (Rogers, 1951) и др. Во 70-тите и 80-тите г. на минатиот век изучувањето се интензивира (Кон, 1978, 1984; Столин, 1983; Wylie, 1974, 1979; и многу други); а последните десетлетија стана експлозивно. Во последните години на 20 век и почетокот на 21 век себството, неговите аспекти и составки се изучуваа во бројни науки и научни области - во скоро сите области на психологијата (особено во психологијата на личноста и социјалната психологија), социологијата, антропологијата, етнологијата, културологијата, лингвистиката, науката за книжевноста, историјата, економијата, политикологијата, невронауката, медицината и др. Користени се разни приоди: интроспективен, феноменолошки, емпириски, експериментален, социолошки, лингвистички, споредбен (посебно т.н. крос-културен), етички, развоен, наративен и др. Постои меѓународно здружение за изучување на себството и идентитетот, специјално списание, се одржаа бројни собири и конференции. Во денешно време во базите на научни податоци има неколку стотини илјади текстови во кои клучен збор е себството. Издадени се илјадници книги и обемни текстови. Во 70-тите и во 80-тите години на минатиот век имаше само една обемна книга, а во денешно време има бројни обемни книги, прирачници и хрестоматии за себството (некои се: Райгородский, 2007; Baumeister, 1999; Bracken, 1996; Gallagher, 2011; Leary, Tangney, 2003, 2012; Schwartz, Luyckx, Vignoles, 2011; Tesser, Felson, Suls, 2000 ). Многубројни се книгите за делови, аспекти, облици и фактори на себството (некои се: Галкина, 2011; Михайлова, Е.В., 2007; Молчанова, 2016; Соколова, 1989, 2015; Чаморро-Премузик, 2014; Alicke, Sedikides, 2011; Arkin, Oleson, Carroll, 2010; Bennett, Sani, 2004; Borders, 2014; Cash, Pruzinsky, 2002; Dainton, 2008; Derlega, Berg, 1987; Ferrari, Sternberg, 1998; Hormuth, 1990; McLean, Syed, 2015; Mruk, 2013; Neisser, 1988, 1993; Vazire, Wilson, 2012; Zahari, Grunbaum, Parnas, 2004). Популарните книги за себството се бројни (на пример, Leary, 2004; Levine, 2016). 


\section{Психологијата на себството во 80-тите години на минатиот век}

Накусо за состојбата на психологијата на себството во 80-тите години на минатиот век и за сознанијата кои беа широко прифатени. (Во тоа време, кај нас терминот себство се користеше крајно ретко.) Вајли (Wylie, 1979) направи преглед на дотогашните истражувања и заклучи дека нема истражувања без недостатоци. Состојбата на теоретизирањето беше незадоволителна. Поврзаноста на истражувањата со теоријата беше слаба. Немаше широкоприфатена определба на себството, на неговите составки и на блиските појави. Себството е сложена појава, а потсистем е на личноста. Два основни аспекти се сознајниот и емоционално-вреднувачкиот. Важна појава е сликата за себе. Уште некои слики се: идеална/сакана, можна, претставена/јавна, „лошо јас“ и др. Клучни појави се себеоценките, а најбитна е глобалната самооцена/себеуважувањето/ себепочитувањето. Себството е поврзано со многу појави, учествува во настанувањето и одржувањето на бројни психички појави. Има повеќе функции. Поврзано е со некои мотиви: за уважување, за пројавување, за стекнување, проширување и унапредување сознанија за себе и др. Себството е поврзано со животните услови, со контекстот; особено важни се односите со другите (,јас“ е неодвоиво од „ти“). Почнува да се развива веќе во првите месеци на животот. Особено важни се промените во пубертетот и младоста.

Натамошниот текст претставува преглед на психологијата на себството во денешно време, т.е. во текстот се содржани широкоприфатени сознанија за себството, посебно за себеоцената, и уште некои сознанија и поставки.

\section{Определба на себството, негови особености и важност}

Последните десетлетија се изнесени бројни определби на себството. Многу од нив значително се разликуваат; себството е определено различно: како севкупност на суштеството, како особа, како личност, како субјект, како извршител, како внатрешна сила, како свест/свесност, како дел/потсистем на личноста, како претстава или сфаќање за себе, како свест за себе итн. (на пример, Мещеряков, Зинченко, 2008; Петровский, 2010а, 2010б; Gallagher, 2011; Leary, Tangney, 2012; Reber, Reber, 2010; Schwartz, Luyckx, Vignoles, 2011). Она што е слично во голем број определби е следното: себството се состои од краткотрајни и долготрајни појави што се однесуваат на себе (претстави, знаења, верувања, оцени и вреднувања, чувствени доживувања, мотиви и др.), а појавите се емоционално-вреднувачки, сознајни (репрезентирачки) и мотивациски.

Некои особености се следниве: Себството е мошне сложено, се состои од многубројни составки. Некои негови составки почнуваат да се градат веќе во 
првата година на животот. Се доградува наредните десетлетија, се менува во текот на сиот животен век. Релативно е постојано, но и динамично, т.е. стабилно и флуидно. Поврзано е со бројни делови/компоненти на личноста - со наравот/ карактерот, вредностите, моралноста и др. (Blasi, 1991; Lapsley, Narvaez, 2004; Narvaez, Lapsley, 2009). Условено е од ситуации, од контекстот.

Себството е важно за менталното функционирање и за човечкото живеење. Некои ментални појави се невозможни без него: долгорочно планирање, животен план, совест, срам, вина, себевоспитување, себеусовршување и др. Некои појави значително се менуваат кога се вклучува себството: разговорот, општењето, соработката, саморегулирањето, себеодржувањето, личниот развој итн.

Оваа појава е еден од клучните услови на создавањето и растот на психологијата.

\section{Составки и функции на себството}

Себството е сложена појава (Јанаков, 2018; Baumeister, 1999; Gallagher, 2011; Leary, Tangney, 2003, 2012; Schwartz, Luyckx, Vignoles, 2011; и др.). Се состои од бројни делови/составки, повеќе области, има повеќе аспекти и повеќе функции. Составките се сознајни, емционално-вреднувачки и мотивациски. Широко е прифатено дека клучна појава, односно појдовна основа за настанувањето и за функционирањето на себството е рефлексијата.

Основни области на себството се: телесно/физичко себство, дејствено себство, социјално себство и ментално себство.

Според сфаќањата на А. Тешфел и следбениците (Tajfel, Turner, Hogg, Abrams и др.; Tajfel, 1982; Ellemers, Haslam, 2012; Hogg, 2006) најважен дел на себството е социјалниот идентитет - поистоветеност со и припадност на дружини, на организации, на класи и на заедницата. Персоналниот идентитет (себедоживувањето, себевреднувањето и др.) зависи од социјалниот идентитет.

Видови знаење за себе (согласно тоа - делови на себството), според У. Нејсер (Neisser, 1988, 1993), се: еколошко, интерперсонално, проширено (лични спомени и предвидувања), приватно и концептуално.

Најголема содржинска појава е сликата за себе. Всушност, опишани се повеќе слики: обична (често наречена реална слика), сакана/идеална, можна, нормативна, јавна, приватна, „несакано јас“, „лошо јас“, проширено себство, социјален идентитет (вклучително етнички идентитет), феноменално себство, слика за животниот пат и уште некои.

Најважна појава е себеоцената, поточно општата себеоцена/себепочитувањето/ себеуважувањето. 
Некои мотиви во врска со себството (според Маралов, 2004; Молчанова, 2016; Baumeister, 1999, 2005; Leary, 2007; Tesser, Felson, Suls, 2000; и др.) се: настанување и одржување (на некој облик) на себство, проширување на себството, откривање на вистината за себе, одржување и зголемување на сопствената важност, себеистакнување, себепотврдување, себеусовршување и себепретставување.

Себството има неколку функции/намени. Бројни психолози ја нагласуваат социјалната. На пример, Баумејстер (Baumeister, 2005, Baumeister, Bushman, 2008, Baumeister, Finkel, 2010 и др.) многу пати тврдеше: себесвесноста и знаењето за себе се потребни за живеењето со другите, во социјалниот контекст. Мек Адамс (McAdams, Cox, 2010; и во други текстови) изјави: прва и најважна улога на себството е та да биде социјален актер. Други функции се себезаштита, обединување/интегрирање на менталноста и др. (Молчанова, 2016; Alicke, Sedikides, 2011 и др.).

Со заштитната функција и со некои од мотивите поврзани се изразена пристрасност кон себе, некои илузии и себеизмамувачки механизми (Taylor, Brown, 1994; и др.). Интересно е тоа што себството може да одреди негативни појави: себепопречување, себенаштетување и др. (тоа посебно е опишано во трудови на Баумејстер и сор., еден труд е Baumeister, 1991). Така, се наштетува со јадење нездрава храна, со претерано или недоволно хранење, пиење алкохол, дрогирање, со ризични активности и со себеповредување.

\section{Себевреднување}

Во психологијата и блиските области во денешно време широко е прифатено: себеоцената е оцена/вреднување на себе си (Молчанова, 2016; Borders, 2014; Donnellan, Trzesniewski, Robins, 2011; Emler, 2001; Mruk, 2013; и др.). Облиците се бројни (Молчанова, 2016; Zeigler-Hill, Jordan, 2010; и др.): општи (себепочитување/себеуважување) и посебни; експлицитни и имплицитни; адекватни и неадекватни; стабилни и менливи; независни и зависни; високи и ниски и др.

Според многу психолози, себепочитувањето е резултат на споредби со определени критериуми. Тие критериуми се поврзани со, односно се идеали, вредности, норми, стандарди, оцени на други луѓе и сл. Условено е од некои мотиви, посебно од потребата за важност. Зависи од односот на сликата за себе со некои од другите слики, особено со саканата слика, како и со оцени на важни луѓе, од споредби сега - минато.

Себеоцената предизвикува чувства, доживувања. 
Мнозинството од луѓето имаат зголемена себеоцена. Зголемувањето делумно е одредено од насоченоста кај себе да се максимизира позитивното, а негативното да се минимизира. Тоа се прави со определени тежнеења и механизми: (1) пристрасност кон себе - успесите се припишуваат на себе, а за неуспесите криви се други луѓе, неповолни услови и сл.; (2) себепреценување - сопствените знаења и особини се преценуваат; (3) селективно помнење за себе (негативните податоци за себе слабо се помнат); (4) претставување на социјално пожелен начин; и (5) подобро од просекот (,јас сум подобар од просекот“).

Во западните земји, особено во САД, последните десетлетија многу се нагласуваше битноста и улогата на високата себеоцена. Таа одредува важни појави: успех во образованието и во работата, добри социјални врски, телесно здравје, ментално здравје, среќа, изгледот, животниот стил итн. А ниската себеоцена одредува бројни негативни појави, вклучително слаб успех во образованието, нарушувања на хранењето, невротични нарушувања, депресија, суицидност, престапништво и криминал. Силно се тврдеше: високата себеоцена обезбедува не само лична, туку и социјална добросостојба, напредок на заедницата. Затоа е потребно себеоцената да се зголемува, а зголемената себеоцена ќе обезбеди лична и социјална добросостојба. Во тие земји се создадоа програми и институции за зголемување на себеоцената (на пример, Caunt, 2003; Helmsetter, 1987; Lindenfields, 1996, 2004). Програмите се остварија со огромен број луѓе. Делумно како резултат на тоа, во поновите истражувања се утврди дека многу жители на САД имаат превисока себеоцена.

Направени се многубројни истражувања и има многу текстови за себепочитувањето и неговите ефекти (некои се: Чаморро-Премузик, 2016; Donnellan et al., 2005; Donnellan, Trzesniewski, Robins, 2011; Mruk, 2013; Orth, Trzsniewski, Robins, 2010, Orth, Robins, Widaman, 2012; Trzesniewski, Donnellan, Moffit, 2006). Голем дел од резултатите на истражувањата се неусогласени.

Во сериозни истражувања (Молчанова, 2016; Emler, 2002; Baumeister et al., 2003 и др.) не се добиени потврди за таквите и толкавите ефекти на себепочитувањето. Општи заклучоци на тие истражувања се следните: Ниската себеоцена не е сосема спротивна на високата себеоцена и, во мнозинството случаи, таа всушност е адекватна (точна) себеоцена. Поголемиот дел од луѓето со пониска себеоцена не се мразат себе си и имаат определени квалитети. Високата себеоцена има не само позитивни туку и негативни ефекти. Таа не е главна причина или предиктор на скоро сите појави за кои се веруваше дека се одредени од неа. Не е пожелно силно да се тежнее кон висока себеоцена. 


\section{Нарушувања на себството}

Во литературата се опишани повеќе нарушувања на себството (Соколова, 1989, 2015; Masterson, Klein, 2013; и др.). Тие тука само се спомнати: криза на идентитет, збрка на идентитет, висока несигурност во себе, себепотценување/ себенепочитување, себепреценување, себевеличие, себељубие/нарцизам, отуѓеност од себе, деперсонализација и поделено јас (двојна или множествена личност).

Себството учествува во настанувањето и одржувањето многубројни нарушувања и негативни појави, односно може да ги услови (Baumeister, 1991; McAdams, 2019; Zeigler-Hill, 2011; и др.); мал дел се следните: депресија, фанатизам, мазохизам, алкохолизам, насилственост, противопштественост, криминално поведение, егоцентричност, себичност, несигурност и суицидност.

\section{Одреденост на себството}

Наредните две поставки се широко прифатени:

- себството е производ на она што единката го прави, на нејзиното дејствување,

- себството се гради и менува во врските со светот, објектите, културата, особено со другите луѓе.

Себството е внатрешна, најприватна појава; се вели дека себството е најпсихолошка од сите психички појави. Ама тоа е општествено условено.

Релативно малку се изучени крос-културните разлики и историската менливост на себството (некои текстови се Cross, Gore, 2003;Wang, Ollendick, 2001). Познато е дека во С Америка се поттикнува индивидуализмот, себичноста, нарцизмот и сл., а во Источна Азија - колективизмот, алтруизмот, милосрдноста и сл. Следствено, себството во С Америка и во Источна Азија значително се разликуваат.

\section{Развој на себството}

Зачетоците на себството се во првите месеци од животот (Harter, 2012; Lipka, Brinthaupt, 1992; McAdams, Cox, 2010; McLean, Syed, 2015; Spencer, Swanson, Harpalani, 2015; Zahari, Grunbaum, Parnas, 2004). Бебињата прават разлика помеѓу себе и предмети, помеѓу себе и други суштества. Во првата година се развива свесност за сопственото тело и за неговата граница. Во втората година децата се препознаваат во огледало и на екрани (на видеоснимки). На 
крајот на втората година кај децата се јавува свест за себе како дејствувачи. Важни показатели на развојот на себството во првите години е користењето на зборовите: јас, мене, мое и на личното име. Во преодниот период насоченоста кон себе се засилува, посебно насоченоста кон личната иднина, и се случуваат важни промени. Во детството и во преодниот период се развиваат сите области и се создаваат бројни составки. Некои развојни линии се: од едноставно кон посложено, од надворешно кон внатрешно, од поединечно кон општо и од конкретно кон апстрактно. Сложеноста на себството многу се зголемува во текот на детството и во преодниот период.

Според резултатите на повеќе истражувања (Harter, 2012; Orth, Robins, 2014; и др.) малите деца имаат позитивно себевреднување, а во преодниот период себевреднувањето може да опадне. Во средната возраст себепочитувањето умерено се зголемува, а после 70 г. често опаѓa (Donnellan, Trzesniewski, Robins, 2011; Orth, Trzsniewski, Robins, 2010; Orth, Robins, 2014).

Добиени се сознанија и за менувањето на себството, посебно во мистични состојби, кај деликвенти и во текот на психотерапија (Brinthaupt, Lipka, 1994; и др.).

\section{Критички осврт за состојбата на психологијата на себството во денешно време}

Во психологијата и блиските науки префиксот себе/само се поврзува со многубројни термини, на пример: себенабљудување, себесвесност, самосвест, самоанализа, себезаштита, самостојност, самопотврдување, самоодредување/ самодетерминација, самооплодување, самоодржување, себеостварување, самозалажување, самозадоволување, самодоволен, самоволие, самовластен, самозван, самодржец, самодисциплиниран, себеслужење, себичност, себебендисаност, себесожалување, саможртвување, самоисмејување, самореклама, себеповредување, самозаборав, самобитен, самооден, самота и самотност, самоделски и самоделец, самообразование и самовоспитување, самоук, саморазвитие, самоник, самоконтрола, саморегулација, самоуправување, самофинансирање и самоубиство. Кованиците се однесуваат на мошне различни појави, а само дел од кованиците се однесуваат на себството, т.е. само дел од наведените појави се изучуваат во психологијата на себството.

Последните десетлетија научната слика за себството значително се обогати. Тоа е прикажано како посложена појава. Особено се збогати описот на процесуалните појави. Извршени се многубројни истражувања на сознајните појави. Во текстовите за себството приличен простор е посветен на мотивите 
и на функциите, особено на саморегулацијата. (Во поново време издадени се бројни книги (на пример, Моросанова, Аронова, 2007; Моросанова, 2013; Ноуle, 2013; Vohs, Baumeister, 2016) и други текстови за саморегулирањето. Меѓутоа, научното изучување на саморегулирањето претежно не припаѓа на психологијата на себството; само дел од процесите и механизмите на саморегулирање се силно поврзани со, односно во голема мера одредени од себството.)

Себството често е претставено како најголем и најважен потсистем на личноста; неретко термините себство и личност се третираат скоро како синоними. Многу луѓе, посебно многу стручњаци, веруваа во исклучително големата важност и пожелност на себството, особено на високата себеоцена и себесвесноста.

Создадени се многубројни сфаќања, грандиозно наречени теории (на пример, Теорија за дискрепанца на Хигинс, Социометарска теорија на Лири, Теорија за себеверификација на Сван и Теорија за одржување на сликата за себе).

Сѐ уште постои збрка во терминологијата. Нема општоприфатени определби на поважните термини и тие не се јасно разграничени. Посебно термините себство, идентитет и јас.

Малку е изучен емоционалниот аспект на себството, односно емоционалните појави. Сознајните појави се многу изучени, но малку се знае за нивната поврзаност со чувствата, мотивите и со активноста, т.е. со живеењето.

Разновидноста и бројот на инструментите за истражување на себството не се доволни, а квалитетот им е слаб.

Истражувањата и теоријата не се достатно поврзани. Состојбата на теоретизирањето е лоша. Теоретскиот дел на психологијата на себството се состои од бројни меѓусебно неповрзани сфаќања; тоа се скоро исклучиво т.н. мини-теории. Поопшти, поопфатни концепции отсуствуваат.

Многу сознанија и сфаќања се меѓусебно несогласни. Така, според некои сфаќања, сликите за себе во значителна мера се поврзани. Но, некои научници, особено постмодернисти, тврдат дека себството е нестабилно, множествено, фрагментирано, разединето и хетерогено.

Јасни и основани одговори за големото мнозинство прашања отсуствуваат. На пример, дали постои општа слика за себе или има бројни кратковремени себедоживувања; дали себството е множествено; дали сликите/претставите се хиерархиски организирани?

Некои древни сфаќања (посебно будистички) и сериозни понови истражувања (в. претходно наведени трудови на Баумајстер, Емлер, Молчанова) ја негираат големата важност и пожелност на себеоцената и/или себството. Себесвесноста 
може да има и неретко има штетни ефекти; превисоката себеоцена, себељубието, себевеличието и сл. појави не се пожелни.

Психологијата на себството многу, дури експлозивно се развиваше последните десетлетија, особено во С Америка. Од занемарена појава, себството стана многу изучувана и популарна појава. Поврзано со тоа, во современата литература, посебно во учебниците и прирачниците, себството често е претставено како најважен потсистем на личноста, како личносно јадро или центар на личноста и опишано е на голем простор, на многу страници. (Опишано е на многу поголем простор одошто карактерот, кој е најважен и најголем потсистем на личноста.) Меѓутоа, видни психолози тоа го негираа. Така, Леонтјев (Леонтьев, 2005) тврди: „јас“ (себството) не е центар на личноста.

Зошто дојде до таква промена? Причините не се претежно научни, туку претежно општествени и идеолошки (в. Соколова, 2015; Lasch, 1986; и др.). Coвременото општество (поточно капитализмот и неолиберализмот) ги лишува луѓето од самостојност, социјално-политичка дејственост (активно учество во општествено-политичкиот живот), слобода и одговорност, ги прави потрошувачи, хедонисти и индивидуалисти, ги насочува кон различност од другите, единственост и исклучителност, т.е. ги поттикнува кон себеистакнување, себевеличење, себељубие. Луѓето не почитуваат норми и ограничувања, стануваат себични, бездушни кон другите, живеат за себе; цел на животот им е личната добросостојба, односно лесно, пријатно и забавно живеење. Отуѓени се еден од друг и од себе.

Од некои сознанија јасно произлегува: себството, неговата „величина“, неговото место во личноста, неговата важност, неговите особености и функции се социјално условени. Една потврда се случувањата во Македонија; последните години некои настани и промени кај нас имаат далекусежно негативно влијание врз идентитетот на Македонците и останатите жители на Македонија. 


\section{Литература}

Ананьев, Б. Г. (1980). Избранные ӣсихолог̄ические йруgы, Т. II. Педагогика.

Валон, А., Зазо, Р. (1988). Дейсйвойо. Наука и изкуство.

Галкина, Т.В. (2011). Самооценка как ӣроцесс решения заgач: Сисйемнный ūogxog. Институт психологии РАН.

Јанаков, Б. (2018). Основи на йерсонолог̄ијайа 1. Филозофски факултет.

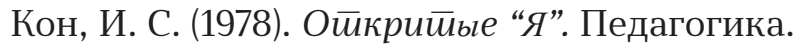

Кон, И. С. (1984). В йоисках себя. Личносйь и ее самосознание. Политиздат.

Маралов, В. Г. (2004). Основы самойознания и саморазвийия, (2е изд.). Изд. Академия.

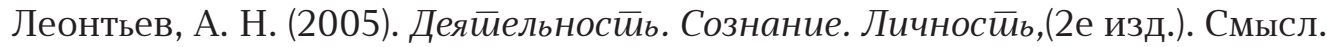

Мещеряков, Б. Г., Зинченко, В.П. (ред.). (2008). Большой йсихолог̄uческий словар,(4е изд.). Прайм-Еврознак.

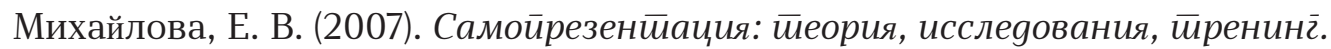
Речь.

Моросанова, В. И. (ред.). (2013). Психолог̄ия саморег̄уляции в ХХІ веке. Нестористория.

Моросанова, В. И., Аронова Е.А. (2007). Самосознание и саморег̄уляция йовеgения. Институт психологии РАН.

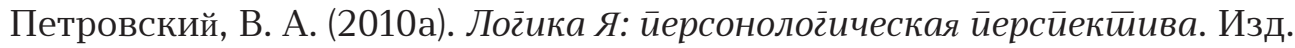
САМГУ.

Петровский, В. А. (2010б). Существует ли Я - субъект познания, воли,

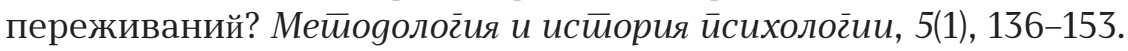

Райгородский, Д. Я. (ред.-сост.). (2007.) Психолог̄ия самосознания: хресииомайия. Бахрах-М.

Сеченов, И. М. (1947). Избранные философские и йсихолог̄ические йроизвеgения. ОГИЗ.

Соколова, Е. Т. (1989). Самосознание и самооценка ӣри аномалиях личносӣи. Московский государственный университет.

Соколова, Е. Т. (2015). Клиническая йсихолог̄uя уйрайы Я. Смысл.

Столин, В. В. (1983). Самосознание личносӣи. Изд. Московского университета.

Чаморро-Премузик, Т. (2014). Уверенносйь во себе. Альпина.

Alicke, M. D., \& Sedikides, C. (Eds.). (2011). Handbook of self-enhancement and selfprotection. Guilford Press. 
Arkin, R. M., Oleson, K. C., \& Carroll, P. J. (Eds.). (2010). Handbook of uncertain self. Psychology Press.

Baumeister, R. F. (1991). Escaping the self: alcoholism, spirituality, masochism, and other flights from the burden of selfhood. Basic Books.

Baumeister, R. F. (Ed.). 1999. Key readings in social psychology: The self in social psychology. Taylor and Francis.

Baumeister, R. F. (2005). Cultural animal: human nature, meaning and social life. Oxford University Press.

Baumeister, R. F., \& Bushman, B. J. (2008). Social psychology and human nature. Thomson.

Baumeister, R. F., Campbell, J.D., Krueger, J .I., \& Vohs, K. D. (2003). Does high self-esteem cause better performance, interpersonal success, happiness, or healthier lifestyle? Psychological Science in the Public Interest, 4(1), 1-44.

Baumeister, R. F., \& Finkel, E. J. (Eds.). (2010). Advanced social psychology. Oxford University Press.

Bennett, M., \& Sani, F. (Eds.). (2004). The development of the social self. Psychology Press.

Blasi, A. (1991). The self as subject in the study of personality. In D. Ozer, J. M. Healy, \& A. J. Stewart (Eds.), Perspectives in personality, (Vol. 3, Part A, pp. 19-37). Kingsley.

Borders, J. H. (Ed.). (2014). Handbook on the psychology of self-esteem. Nova.

Bracken, B. A. (Ed.). (1996). Handbook of self-concept: developmental, social, and clinical considerations. Wiley.

Brinthaupat, T. M., \& Lipka, R. P. (Eds.). (1994). Changing the self: Philosophies, techniques, and experiences. SUNY press.

Cash, T. F., \& Pruzinsky, T. (Eds.). (2002). Body image: a handbook of theory, research, and clinical practice. Guilford Press.

Caunt, J. (2003.) Boost your self-esteem. Kogan Page.

Cross, S. E., \& Gore, J. S. (2012). Cultural models of the self. In M. R. Leary \& J. P. Tangney (Eds.), Handbook of self and identity (p. 587-614). The Guilford Press.

Dainton, B. (2008). The phenomenal self. Oxford University Press.

Derlega, V. J., \& Berg, J. H. (Eds.). (1987). Self-disclosure: Theory, research, and therapy. Springer Science \& Business Media.

Donnellan, B. M., Trzesniewski, K. H., Robins, R. W., Moffit, T. E., \& Caspi, A. (2005). Low self-esteem is related to aggression, antisocial behavior, and delinquency. Psychological Science, 16(4), 328-335. 
Donnellan, B. M., Trzesniewski, K.H., \& Robins, R.W. (2011). Self-esteem: enduring issues and contaversies. In T. Chamorro-Premuzic, S. Stumm, A. Furnham. (Eds.) The Wiley Blackwell handbook of individual differences. Wiley Blackwell.

Ellemers, N., \& Haslam, S. A. (2012). Social identity theory. In P. A. M. Van Lange, A. W. Kruglanski, \& E. T. Higgins (Eds.), Handbook of theories of social psychology (p. 379-398). Sage Publications Ltd.

Emler, N. (2001). Self-esteem. The coast and causes of low self-worth. York Publishing Service.

Erikson, E. H. (1963). Childhood and society. Norton.

Ferrari, M., \& Sternberg, R. J. (Eds.). (1998). Self-awareness: its nature and development. Guilford.

Harter, S. (2012). The construction of the self: Developmental and sociocultural foundations, (2nd ed.). Guilford.

Helmstetter, S. (1987). The self-talk solution. William Morrow \& Co.

Higgins, E. T. (1999). Self-discrepancy: A theory relating self and affect. In R. F. Baumeister (Ed.), Key readings in social psychology. The self in social psychology (p. 150-181). Psychology Press.

Hormuth, S. E. (1990). The ecology of the self: Relocation and self-concept change. Cambridge University Press.

Hoyle, R. H. (Ed.). (2013). Handbook of personality and self-regulation. Wiley.

Gallagher, S. (Ed.). (2011). The Oxford handbook of the self. Oxford University Press.

James, W. (1950). The principles of psychology. Dover.

Janakov, B. (1988). Psihologija samosvesti. IICSSO.

Lapsley, D. K., \& Narvaez, D. (Eds.). (2004). Moral development, self, and identity. Erlbaum.

Lasch, C. (1986). Narcisticka kultura. Naprijed.

Leary, M. (2004). The curse of the self: self-awareness, egotism, and the quality of human life. Oxford University Press.

Leary, M. (2007). Motivational and emotional aspects of the self. Annual Review of Psychology, 58, 317-344.

Leary, M., \& Tangney, J. P. (Eds.). (2003). Handbook of self and identity. Guilford Press.

Leary, M., \& Tangney, J. P. (Eds.). (2012). Handbook of self and identity. (2nd ed.). Guilford Press. 
Levine, R. V. (2016). Strangers in the mirror: the scientific search for the self. Princeton University Press.

Lindenfield, G. (1996). Self-esteem. Harper Collins.

Lindenfield, G. (2004). Self-esteem bible: Build your confidence day by day. Harper Collins.

Lipka, R. P., \& Brinthaupat, T. M. (Eds.). (1992). Self-perspectives across life span. SUNY Press.

Masterson, J. F., \& Klein, R. (Eds.). (2013). Disorders of the self: New therapeutic horizons: The Masterson approach. Brunner-Mazel.

McAdams, D. P. (2019). Psychopathology and the self: Human actors, agents, and authors. Journal of Personality, 8(3), 272-295.

McAdams, D. P., \& Cox, K. S. (2010). Self and identity across life span. Bo R.M. Lerner, M.E. Lamb, A.M. Freund. (Eds.). Handbook of life span development. Wiley.

McLean, K. C., \& Syed, M. (Eds.). (2015). The Oxford handbook of identity development. Oxford University Press.

Mruk, C. J. (2013). Self-esteem and positive psychology: Research, theory, and practice. (4th ed.). Springer Publishing Company.

Narvaez, D., \& Lapsley, D. K. (Eds.). (2009). Personality, identity, and character: Exploration in moral psychology. Cambridge University Press.

Neisser, U. (1988). Five kinds of self-knowledge. Philosophical Psychology, 1(1), 35-59.

Neisser, U. (Ed.). (1993). Five kinds of self-knowledge: Ecological and interpersonal sources of self-knowledge. Cambridge University Press.

Olport, G. (1969). Sklop i razvoj licnosti. Kultura.

Orth, U., Trzsniewski, \& S. H., Robins, R. (2010). Self-esteem development from young adulthood to old age: a cohort-sequential longitudinal study. Journal of Personality and Social Psychology, 98(4), 645-658.

Orth, U., Robins, R., \& Widaman, K. F. (2012). Life span development of selfesteem and its effects on important life outcomes. Journal of Personality and Social Psychology, 102(6), 1271-1288.

Orth, U., \& Robins, R. (2014). The development of self-esteem. Current Directions in Psychological Science, 23(5), 381-387.

Reber, A. S., \& Reber, E. S. (2010). Recnik psihologije. Sluzbeni glasnik.

Rogers, C. R. (1951). Client-centered therapy; its current practice, implications, and theory. Houghton Mifflin. 
Schwartz, S. J., Luyckx, K., \& Vignoles, V. L. (Eds.). (2011). Handbook of identity theory and research, (Vols. 1-2). Springer.

Spencer, M. B., Swanson, D. P., \& Harpalani, V. (2015). Development of the self. In M. E. Lamb (Vol. Ed.), R. M.Lerner (Ed.-in-chief), Handbook of child psychology and developmental science: Vol. 3. Socioemotional processes. (7th ed., pp. 750-793). Wiley.

Tajfel, H. (ed.). (1982). Social identity and intergroup relations. Cambridge University Press.

Taylor, S. E.; \& Brown, J. D. (1994). Positive illusions and well-being revisited: Separating fact from fiction. Psychological Bulletin. 116(1), 21-27.

Tesser, A., Felson, R. B., \& Suls, J. M. (Eds.). (2000). Psychological perspectives on self and identity. American Psychological Association.

Trzesniewski, K. H., Donnellan, B. M., \& Moffit, T. (2006). Low self-esteem during adolescence predicts poor health, criminal behavior, and limited economic prospects during adulthood. Developmental Psychology, 42(2), 381-390.

Valon, A. (1985). Psihicki razvoj deteta. Zavod za udzbenike.

Vazire, S., \& Wilson, T.D. (Eds.). (2012). Handbook of self-knowledge. Guilford.

Vohs, K. D., \& Baumeister, R. F. (Eds.). (2016). Handbook of self-regulation, (3rd ed.). Guilford.

Wang, Y., \& Ollendick, T. H. (2001). A cross-cultural and developmental analysis of self-esteem in Chinese and Western children. Clinical Child and Family Psychology Review, 4(3), 253-271.

Wylie, R. (1974). The self-concept. (Vol. I). University of Nebraska Press.

Wylie, R. (1979). The self-concept: Theory and Research in selected topics. (Vol. II). University of Nebraska Press.

Zahari, D., Grunbaum, T., \& Parnas, J. (Eds.). (2004). The structure and development of self-consciousness. John Benjamins.

Zeigler-Hill, V. (2011). The connections between self-esteem and psychotherapy. Journal of Contemporary Psychotherapy, 41(3), 157-164.

Zeigler-Hill, V., Jordan, C. H. (2010). Two faces of self-esteem: implicit and explicit forms of self-esteem. In Gawronski, B., \& K. Payne. (Eds.), Handbook of implicit social cognition: Measurement, theory, and applications. Guilford press. 


\title{
PSYCHOLOGY OF THE SELF TODAY
}

\section{Blagoja Janakov}

\begin{abstract}
Great number of psychologists studied the self in the last decades. The self is one of the few most studied phenomena in contemporary psychology. According to many psychologists, especially from North America, the self is the most important or the main part/ subsystem of the personality. It is a fact that scientific knowledge about the self in the last decades has been increased, especially knowledge about processual phenomena, about the self functioning. The knowledge about the relations of the self (which, according to some psychologists, is the most inner, most psychological mental phenomena) with the world, mainly with social context is considerably enriched. A part of the text is about the key component of the self - self-esteem, self-regard. There are many views (including the so called theories) about parts, aspects and mechanisms of the self. Many new questions about the self has been raised. But the key questions about the self has not yet been answered with proofs and cogent arguments.
\end{abstract}

Keywords: the self, the self concept, self-consciousness, self-esteem, self-regard 